\title{
Spanish translation of the Kihon Checklist (frailty index)
}

\author{
Ana Maseda, ${ }^{1}$ Laura Lorenzo-López, ${ }^{1}$ Rocío López-López, ${ }^{1}$ Hidenori Arai, ${ }^{2}$ José C. \\ Millán-Calenti, ${ }^{1}$ \\ ${ }^{1}$ Gerontology Research Group, Instituto de Investigación Biomédica de A Coruña (INIBIC), Complexo Hospitalario \\ Universitario de A Coruña (CHUAC), SERGAS, Universidade da Coruña A Coruña, Spain, \\ ${ }^{2}$ National Center for Geriatrics and Gerontology, Obu, Aichi Japan
}

Dear Editor,

Frailty syndrome is "a clinical state in which there is an increase in an individual's vulnerability for developing dependency and/or mortality when exposed to a stressor".[1] It is one of the main reasons for morbidity and premature mortality in older adults, and there is not a clear consensus on its definition.[2] The prevalence of frailty and prefrailty states varies from $4.9 \%$ to $27.3 \%$ and from $34.6 \%$ to $50.9 \%$, respectively, in representative samples of community-dwelling adults aged 65 years and older.[3] Frailty screening is required to limit its important impact on public health burden.[4] Nowadays, there are a high number of frailty measurements considering different operational definitions.[2] One of these instruments is the Kihon Checklist (KCL), recently validated and widely used in Japan.[5, 6] An English translation of the KCL was published with the aim of being used for no Japanese speakers involved in older adults care.[7] This English translation has 25 yes/no questions, with items divided into seven categories: activities of daily living, physical strength, nutritional status, oral function, isolation, memory and mood. Scores range from 0 (no frailty) to 25 (high frailty), and individuals scoring more than 9 points in the lifestyle domain are considered frail.[5, 8] Scoring in the different domains of this screening test also identifies lower functions, such as lower physical strength (three points or more), lower nutritional (two points)/oral status (two points or more), lower cognitive function (one or more points), houseboundness (negative answer on question 16) and depression risk (two points or more).[5, 8] The KCL has also been validated to the Brazilian Portuguese language.[8]

In 2015, the Spanish-speaking population represented $6.7 \%$ of the world's population (approximately 470 million people), with an expected percentage of $7.5 \%$ by 2030,[9] with more than 46 million in Spain. The Spanish older population is growing enormously. By 2050, 37\% of Spain's population will be aged 65 years or older.[10] Aging increases the frequency of aging-associated diseases that often manifest in frailty,[2] and screening validated tests are required to allow geriatricians and gerontologists to identify frail and prefrail older adults.[1]

Considering this approach, the aim of the present study was to provide an official Spanish translation of the KCL to assess frailty in Spanish speakers. 
The Spanish translation was made following a forward-backward translation sequence from the KCL English version. A committee of 12 health professionals with experience in gerontological assessment and older adults care that did not have previous knowledge of the KCL were involved in the translation procedure. They were divided into two groups. Each native Spanish-speaking researcher of the first group translated the KCL into Spanish, and after this, a gerontology expert considered all the contributions and edited the final version. A focus group including the researchers involved in the first phase of the translation was carried out, and they reviewed and discussed the preliminary Spanish version for ensuring accuracy and comprehensibility among older adults. Next, each researcher of the second group of the committee made a back-translation from this preliminary Spanish version into English, and all the backtranslations were edited to an only English translated version by a gerontologist who was blind to the research procedure. A second focus group reviewed and discussed this back-translated version, which was compared with the original English version and semantic equivalence was found.[7]

Lastly, the authors used a machine translation interface to directly translate the original Japanese version of the KCL (http://www.mhlw.go.jp/topics/2009/05/dl/tp0501-1c_0001.pdf) into Spanish. The committee compared their Spanish translation with the machine-translation version, finding relevant similarities among the main terms of the KCL, and confirming the adequacy of the terms used in the translation.

Finally, we approved the final KCL Spanish translation (KCL-ES; Table 1). KCL-ES will allow frailty assessment of Spanish-speaking older adults, considering the recommendation that older adults aged 70 years and older, and all those with significant weight loss $(\geq 5 \%)$ as a result of chronic illness should be screened for frailty by healthcare providers.[1] The use of this translated screening tool is recommended for future research to offer a cross-cultural validation and reliability of its use in Spanishspeakers. In future studies, it would also be interesting to compare the frailty prevalence identified by the KCL-ES with that found by other frailty indexes. 
Table 1. Spanish translation of the Kihon Checklist

\section{ESTILO DE VIDA}

Respuesta

1. ¿Utiliza el bus o el tren por sí mismo/a?

0. Sí 1. No

2. ¿Hace la compra diaria por sí mismo/a?

0. Sí 1. No

3. ¿Gestiona usted directamente sus asuntos con el banco?

0. Sí 1. No

4. ¿Visita a sus amigos alguna vez?

0. Sí 1. No

5. ¿Recurre a su familia o amigos para pedir consejo?

0 . Sí 1. No

\section{Fuerza física}

6. Normalmente, ¿sube las escaleras sin usar el pasamanos o apoyarse en la pared?

7. Normalmente, ¿se levanta de la silla sin ninguna ayuda?

8. Normalmente, ¿camina durante 15 minutos de forma continua?

9. ¿Ha sufrido alguna caída en el último año?

10. ¿Tiene miedo a caerse mientras camina?

\section{Estado nutricional}

11. ¿Ha perdido 2 o más $\mathrm{kg}$ en los últimos 6 meses?

12. Altura: cm; Peso: kg; IMC: kg/m2. Si el IMC es menor de 18,5, este ítem puntúa "sí"

Función oral

13. ¿Tiene alguna dificultad para ingerir alimentos sólidos/duros en comparación a los últimos 6 meses? $\quad 1$. Sí $\quad 0$. No

14. ¿Se ha atragantado recientemente al tomar líquidos (ej. agua o sopa)?

15. ¿Nota a menudo la boca seca?

Reclusión en el hogar

16. ¿Sale de casa al menos una vez a la semana?

17. ¿Sale de casa menos que el año pasado?

Función cognitiva

18. ¿Su familia o sus amigos le comentan que pierde memoria? Por ejemplo: "Haces la misma pregunta una y otra vez."

19. ¿Hace llamadas de teléfono buscando usted mismo los números?

20. Con frecuencia, ¿no sabe qué día es?

1. Sí $\quad 0$. No

\section{RIESGO DE DEPRESIÓN}

21. En las últimas 2 semanas, ¿está menos satisfecho con su vida diaria?

22. En las últimas 2 semanas, ¿disfruta menos con las cosas con las que antes solía disfrutar?

23. En las últimas 2 semanas, ¿le cuesta más hacer cosas que antes hacía fácilmente?

1. Sí $\quad$ 0. No

24. En las últimas 2 semanas, ¿se ha sentido inútil?

1. Sí $\quad 0$. No

25. En las últimas 2 semanas, ¿se ha sentido cansado/a sin motivo aparente?

1. Sí 


\section{References}

1. Morley JE, Vellas B, van Abellan KG et al. Frailty consensus: A call to action. J Am Med Dir Assoc 2013; 14 (6): 392-397.

2. Dent E, Kowal P, Hoogendijk EO. Frailty measurement in research and clinical practice: A review. Eur J Intern Med 2016; 31: 3-10.

3. Choi J, Ahn A, Kim S, Won WC. Global prevalence of physical frailty by Fried's criteria in community-dwelling elderly with national population-based surveys. JAMDA 2015; 16 : 548-550.

4. Buckinx F, Rolland Y, Reginster JY, Ricour C, Petermans J, Bruyère O. Burden of frailty in the elderly population: Perspectives for a public health challenge. Arch Public Health 2015; 73: 19 .

5. Fukutomi E, Okymiya K, Wada T et al. Relationships between each category of 25-item frailty risk assessment (Kihon Checklist) and newly certified older adults under LongTerm Care Insurance: A 24-month follow-up study in a rural community in Japan. Geriatr Gerontol Int 2015; 15: 864-871.

6. Satake S, Senda K, Hong YJ et al. Validity of the Kihon Checklist for assessing frailty status. Geriatr Gerontol Int 2016; 16: 709-715.

7. Arai H, Satake S. English translation of the Kihon Checklist. Geriatr Gerontol Int 2015; 15: 518-519.

8. Sewo Sampaio PY, Sampaio RAC, Yamada M, Ogita M, Arai H. Validation and translation of the Kihon Checklist (frailty index) into Brazilian Portuguese. Geriatr Gerontol Int 2014; 14 (3): 561-569.

9. Instituto Cervantes. El español una lengua viva- Informe 2015. Madrid: Instituto Cervantes, 2015 Spanish.

10. Bosch X. Spain faces massive decline in population. BMJ 2000; 320 (7239): 891. 